\title{
A STUDY OF VASCULAR CHANGES DURING SURGERY OF PARAPLEGIC PATIENTS
}

\author{
By C. F. CARoN, M.D., and E. Bors, M.D. \\ From the Anaesthesiology Section, Surgical Service, and the Spinal Cord Injury Service, \\ Veterans Administration Hospital, Long Beach, California, and the Departments of Surgery, \\ University of California School of Medicine at Irvine and at Los Angeles, California \\ IT is well known that patients with spinal cord injuries, especially with high thoracic \\ or cervical lesions, frequently manifest labile vascular systems. Because of this, \\ we were interested in changes of blood pressure during various surgical procedures, \\ and studied these changes during surgery, with and without anaesthesia. Among \\ several papers dealing with anaesthesia in paraplegic patients, only Ciliberti (1954) \\ reported on blood pressure changes.
}

\section{MATERIAL AND METHODS}

A total of 97 patients ranging in age from 19 to 70 years with 257 procedures were evaluated. The blood pressure changes were analysed in regard to the level and extent of the lesion, to the type of operative procedure, and to the anaesthetic agent.

The anaesthetic agents used were sodium pentobarbital, nitrous oxide, halothane, spinal pontocaine, cyclopropane, and endotracheal intubation and succinylcholine chloride were an adjunct to the anaesthesia during neurosurgery and renal surgery, or if the position of the patient required intubation to maintain a patent airway. The pre-operative medication consisted of hydroxyzine hydrochloride and atropine sulphate and, infrequently, small doses of secobarbital.

Inasmuch as this was a practical clinical study we chose the following procedure in order to determine significant blood pressure changes: blood pressure readings were taken prior to surgery and, in addition, the baseline of blood pressure on the respective patient had been established before surgery during his observation and treatment on the ward. The patient's blood pressure was again determined during the induction of anaesthesia or in cases without anaesthesia, at the time of incision. Thereafter, blood pressure was observed at five-minute intervals during the procedure. Blood pressure readings were taken at the completion of the procedure and again upon returning to the ward. We considered blood pressure changes as significant when the fluctuation exceeded $20 \mathrm{ml}$. of mercury after taking into consideration that this difference must be evaluated in correlation with the baseline of each patient.

Table I illustrates that blood pressure changes were observed in 27 of 97 patients $(27.8$ per cent.). The table also shows the distribution in regard to level and extent of injury. More frequently changes occurred in patients with high thoracic and cervical cord lesions, with the exception of Group V. These two patients had high thoracic spinothalamic tractotomies, although they had originally complete lumbar lesions. Therefore, their lesions became incomplete high thoracic lesions by virtue of the cordotomy. Another exception was that of one 
TABLE I

\begin{tabular}{|c|c|c|c|c|c|c|c|}
\hline \multirow{2}{*}{ Group } & \multirow{2}{*}{ Level of lesion } & \multirow{2}{*}{$\begin{array}{l}\text { No. of } \\
\text { Patients }\end{array}$} & \multirow{2}{*}{$\begin{array}{l}\text { No. of } \\
\text { Procedures }\end{array}$} & \multicolumn{2}{|c|}{ Blood pressure changes } & \multicolumn{2}{|c|}{ Procedures } \\
\hline & & & & Patients & Procedures & $\begin{array}{l}\text { Blood pressure } \\
\text { rise }\end{array}$ & $\begin{array}{l}\text { Blood pressure } \\
\text { drop }\end{array}$ \\
\hline I & $\begin{array}{l}\text { Complete cervical cord } \\
\text { lesions }\end{array}$ & I8 & 46 & $\begin{array}{c}5 \\
27 \%\end{array}$ & 8 & 5 & 3 \\
\hline II & $\begin{array}{l}\text { Incomplete cervical cord } \\
\text { lesions }\end{array}$ & 22 & 63 & 40\% & I 8 & 13 & 5 \\
\hline III & $\begin{array}{l}\text { Complete thoracic cord } \\
\text { lesions TI-T6 }\end{array}$ & IO & 46 & 5 & I8 & 9 & 9 \\
\hline IV & $\begin{array}{l}\text { Complete thoracic cord } \\
\text { lesions } \mathrm{T}_{7}-\mathrm{T}_{12}\end{array}$ & $3 I$ & 43 & $\begin{array}{l}5 \\
16 \%\end{array}$ & I3 & 4 & 9 \\
\hline V & $\begin{array}{l}\text { Complete thoracic cord } \\
\text { lesions LI-L5 }\end{array}$ & 4 & 26 & $\begin{array}{c}2 \\
50 \%\end{array}$ & 8 & 7 & I \\
\hline VI & $\begin{array}{l}\text { Incomplete thoracic cord } \\
\text { lesions TI-T6 }\end{array}$ & 5 & 12 & $\begin{array}{l}\text { No } \\
\text { changes }\end{array}$ & $\begin{array}{l}\text { No } \\
\text { changes }\end{array}$ & - & - . \\
\hline VII & $\begin{array}{l}\text { Incomplete thoracic cord } \\
\text { lesions } T_{7}-T_{12}\end{array}$ & 3 & 6 & $\begin{array}{c}\text { No } \\
\text { changes }\end{array}$ & $\begin{array}{c}\text { No } \\
\text { changes }\end{array}$ & - & 一 \\
\hline VIII & $\begin{array}{l}\text { Incomplete thoracic cord } \\
\text { lesions } \mathrm{L}_{\mathrm{I}}-\mathrm{L}_{5}\end{array}$ & 4 & I5 & $\begin{array}{l}\mathrm{I} \\
25 \%\end{array}$ & 2 & 2 & - \\
\hline
\end{tabular}


TABle II

\begin{tabular}{|c|c|c|c|c|c|c|}
\hline \multirow[b]{2}{*}{ Group } & \multirow[b]{2}{*}{ Procedures } & \multirow[b]{2}{*}{ Type of procedure } & \multicolumn{2}{|c|}{ Blood pressure changes } & \multirow{2}{*}{${ }_{\text {rise }}^{\text {Blood pressure }}$} & \multirow{2}{*}{$\begin{array}{l}\text { Blood pressure } \\
\text { drop }\end{array}$} \\
\hline & & & Number & Percentage & & \\
\hline I & 25 & Renal operations & 19 & 76 & I4 & 5 \\
\hline II & 3 & Neurosurgery operations & 2 & 66 & 2 & \\
\hline III & 85 & $\begin{array}{l}\text { Decubitis repair without } \\
\text { ostectomy }\end{array}$ & 8 & $9 \cdot 5$ & 3 & 5 \\
\hline IV & 45 & $\begin{array}{l}\text { Decubitus repair with } \\
\text { ostectomy }\end{array}$ & 17 & $37 \cdot 5$ & 6 & II \\
\hline $\mathrm{V}$ & 13 & $\begin{array}{l}\text { Abdominal or thoracic } \\
\text { operations }\end{array}$ & 2 & I5 & I & I \\
\hline VI & 23 & $\begin{array}{l}\text { Peripheral neurotomy and } \\
\text { tenotomy }\end{array}$ & 2 & $8 \cdot 5$ & - & 2 \\
\hline VII & 63 & Vesical or perineal operations & I7 & 26 & I4 & 3 \\
\hline Totals & 257 & & 67 & 26 & 40 & 27 \\
\hline
\end{tabular}


TABLE III

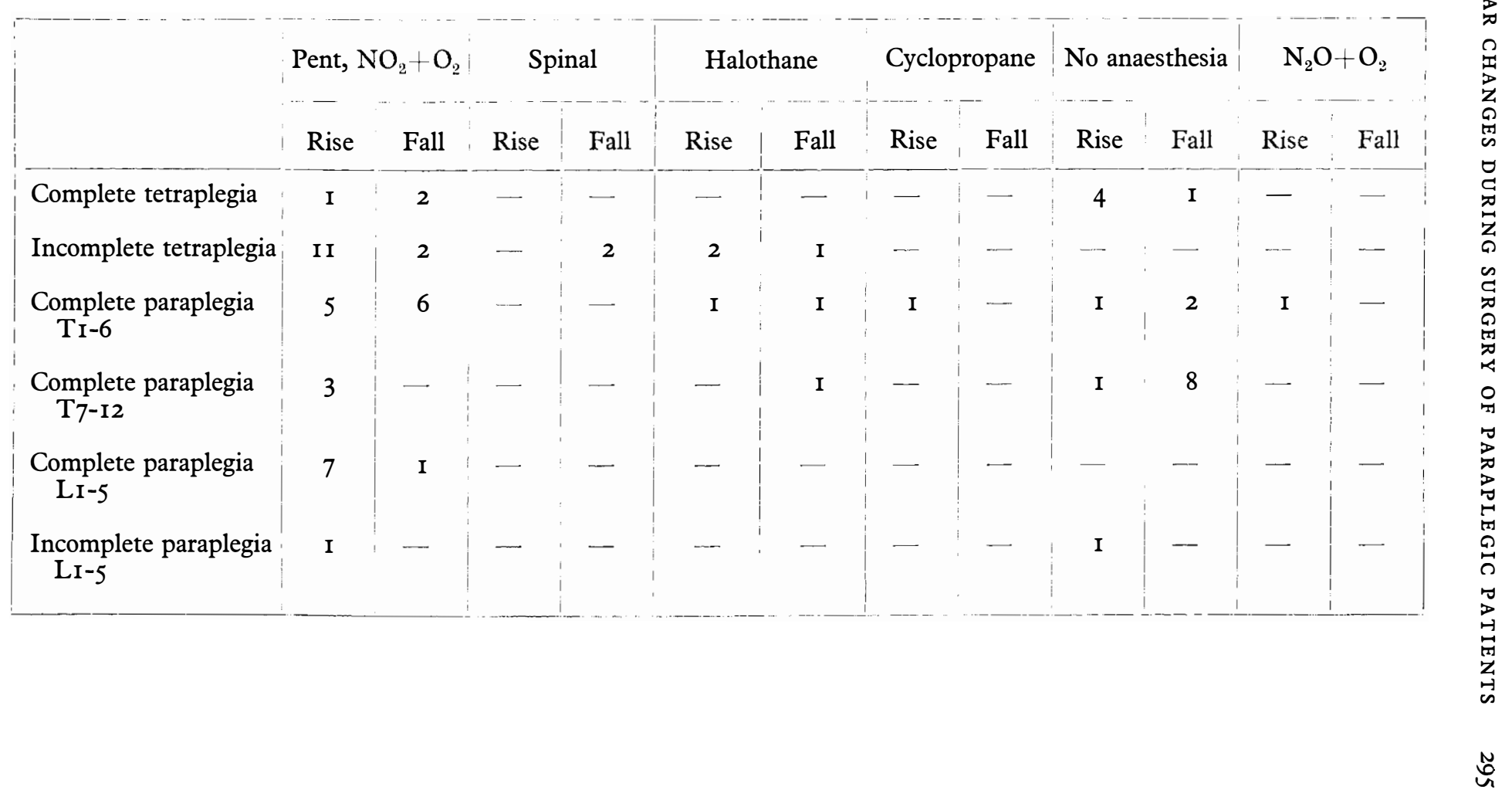


TABle IV

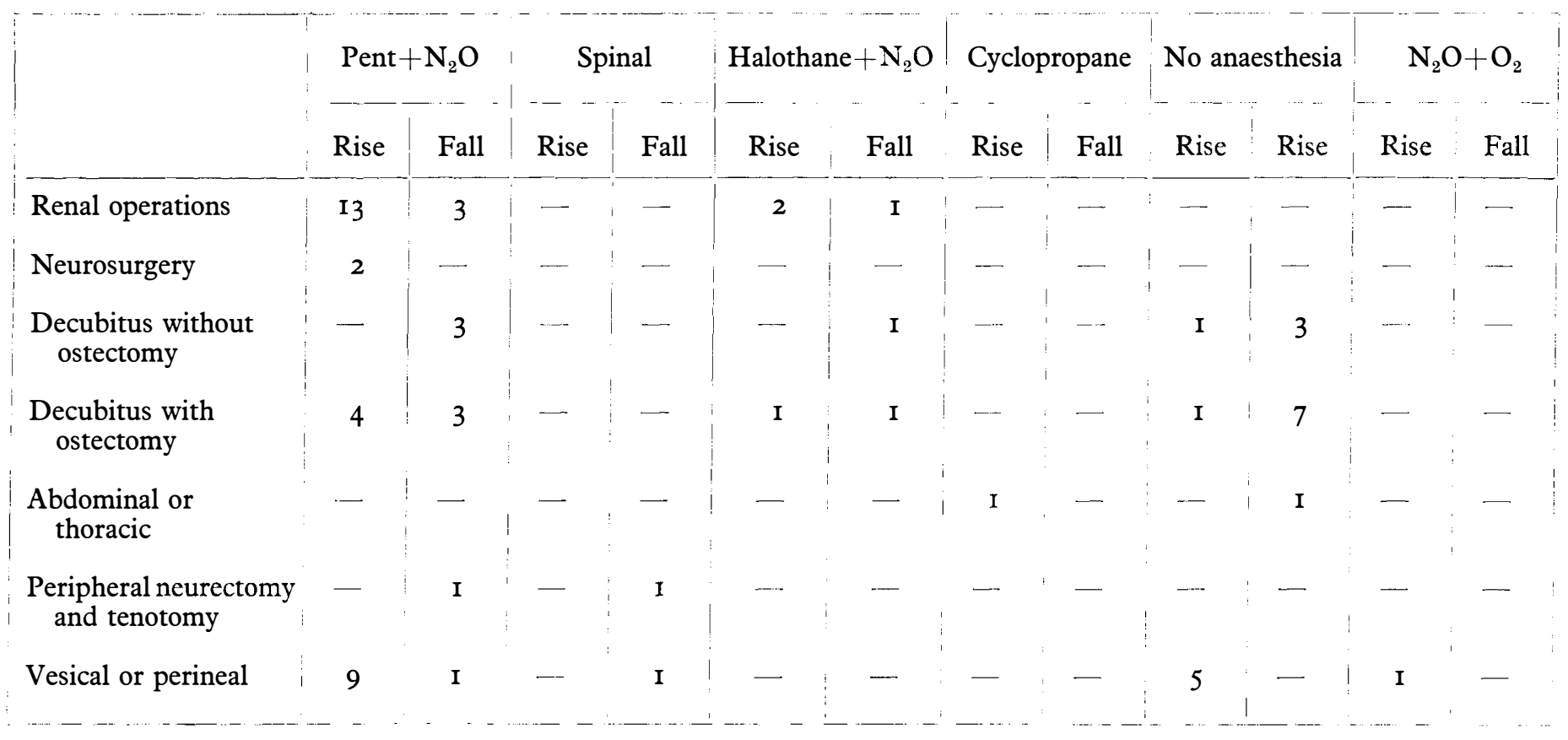


patient in Group VIII whose blood pressure changes were the result of hypertensive disease, rather than autonomic dysreflexia.

Table II illustrates the relation of various interventions to blood pressure changes. Analysis of the various procedures categorised in Groups I through VII gave the following information: In Group I, the renal operations were pyelostomies or nephrostomies, but not nephrectomies. All but one of the I 4 procedures showing a rise in blood pressure concerned patients with lesions above the splanchnic outflow:

Group II: One high thoracic spinothalamic tractotomy and one cervical laminectomy were accompanied by a blood pressure rise, whereas, an anterior rhizotomy did not have this effect.

Group III: Decubitus ulcer surgery without ostectomy caused very little change; a rise of blood pressure in two patients was explained by the high level of their lesion. Another patient showed a rise of blood pressure, however, his spinal cord lesion was accompanied with cerebrovascular lues.

Group IV: Decubitus ulcer surgery with ostectomy showed a higher incidence of blood pressure changes. As was expected, a drop in blood pressure was more frequent because of the extensive surgery with blood loss.

Group V: One can observe that blood pressure changes were infrequent during abdominal and thoracic operations. Gastric and thoracic operations were accompanied by a rise in blood pressure if the spinal cord lesion was above the splanchnic outflow. Other procedures of minor magnitude did not show a rise in blood pressure even in presence of lesions above the splanchnic outflow.

Group VI: During peripheral neurotomies, myotomies, and/or tenotomies, blood pressure changes were seldom observed. The two instances of blood pressure drop were explained by spinal anaesthesia in one patient, and a prior subarachnoid alcohol injection in the other.

Group VII: During vesical and perineal operations changes were frequent and the table illustrates a trend toward a blood pressure rise. This was attributed to the level of the lesion, previous spinothalamic tractotomy, or hypertensive disease.

In summary, 67 procedures of 257 were accompanied with blood pressure changes. The ratio between a rise and fall in blood pressure totaled 40:27 (59.7 per cent :: 40.3 per cent.).

\section{DISCUSSION}

Table $\mathrm{V}$ shows a correlation of blood pressure changes with the level and extent of the lesion and the type of procedure. As was to be expected, autonomic dysreflexia, as discussed by Guttmann and Whitteridge (1947) and by Bors and French (1952), played the major role in creating blood pressure changes. The type of intervention was second in importance. The anaesthetic did not seem to precipitate blood pressure changes, but the depth of the anaesthesia was important in the control of blood pressure rises caused by autonomic dysreflexia. The depression of an elevated blood pressure by deepening the anaesthetic plane was far more gradual and controllable than the abrupt effect of a ganglioplegic agent (hexamethonium chloride). Ciliberti et al. (1954) have also observed that a deeper plane of anaesthesia suppressed autonomic dysreflexic responses, but still seemed to give preference to hexamethonium for such suppression rather than to increase the depth of anaesthesia. 
TABle V

\begin{tabular}{|c|c|c|c|c|c|c|c|c|c|c|c|c|c|}
\hline \multirow[t]{2}{*}{ Procedures } & \multicolumn{2}{|c|}{$\begin{array}{c}\text { Complete } \\
\text { tetraplegia } \\
\text { blood pressure }\end{array}$} & \multicolumn{2}{|c|}{$\begin{array}{c}\text { Incomplete } \\
\text { tetraplegia } \\
\text { blood pressure }\end{array}$} & \multicolumn{2}{|c|}{$\begin{array}{c}\text { Complete } \\
\text { paraplegia } \\
\text { TI-6 } \\
\text { blood pressure }\end{array}$} & \multicolumn{2}{|c|}{$\begin{array}{c}\text { Complete } \\
\text { paraplegia } \\
\text { T7-I2 } \\
\text { blood pressure }\end{array}$} & \multicolumn{3}{|c|}{$\begin{array}{c}\text { Complete } \\
\text { paraplegia } \\
\text { LI-5 } \\
\text { blood pressure }\end{array}$} & \multicolumn{2}{|c|}{$\begin{array}{c}\text { Incomplete } \\
\text { paraplegia } \\
\text { LI-5 } \\
\text { blood pressure }\end{array}$} \\
\hline & Rise & Fall & Rise & Fall & Rise & Fall & Rise & Fall & Rise & & Fall & Rise & Fall \\
\hline $\begin{array}{l}\text { Renal } \\
\text { I2 Patients }\end{array}$ & 2 & I & 7 & I & I & 2 & - & I & 3 & 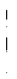 & - & I & - \\
\hline $\begin{array}{l}\text { Neurosurgery } \\
2 \text { Patients }\end{array}$ & 一 & - & I & - & - & $\cdots$ & -- & - & I & & $+\cdots-$ & - & - \\
\hline $\begin{array}{l}\text { Decubitus without } \\
\text { ostectomy } \\
6 \text { Patients }\end{array}$ & - & - & - & I & 2 & I & I & 3 & -- & & - & - & - \\
\hline $\begin{array}{l}\text { Decubitus with } \\
\text { ostectomy } \\
\text { Io Patients }\end{array}$ & I & 一 & - & - & 5 & 6 & - & 5 & -- & & - & - & - \\
\hline $\begin{array}{l}\text { Abdominal or thoracic } \\
2 \text { Patients }\end{array}$ & - & I & - & - & I & - & -- & - & - & & $\ldots$ & - & - \\
\hline $\begin{array}{l}\text { Neurectomy and } \\
\text { tenotomy } \\
2 \text { Patients }\end{array}$ & - & - & - & 2 & - & - & - & - & - & & - & $\ldots$ & - \\
\hline $\begin{array}{l}\text { Vesical or perineal } \\
9 \text { Patients }\end{array}$ & 3 & - & 5 & I & -- & - & 3 & - & 3 & & I & I & - \\
\hline
\end{tabular}


Autonomic dysreflexia was usually observed in patients with complete or incomplete cervical lesions and less frequently with complete thoracic lesions above the splanchnic outflow. Autonomic dysreflexia was observed in five patients with complete cervical lesions with various levels between $\mathrm{C}_{5}$ and $\mathrm{C}_{7}$, in patients with incomplete lesions with similar levels, and in five patients with complete high thoracid lesions $\mathrm{T}_{4}, \mathrm{~T}_{5}$, and $\mathrm{T} 6$. In addition, two patients with low levels $\left(\mathrm{L}_{3}\right)$ showed autonomic dysreflexia because of a previous spinothalamic tractotomy. Similar observations have been reported by Ciliberti et al. (1954). These authors also found infrequent changes in patients with lesions below the splanchnic outflow which we found in only one patient during renal surgery. No rise of blood pressure occurred in patients with incomplete thoracic lesions above or below the splanchnic outflow.

In contrast, there was a blood pressure rise in two patients with a previous spinothalamic tractotomy whose lesions were complete between LI and L5. Spinothalamic tractotomy interferes with the autonomic afferent and efferent pathways within the spinal cord; in our patients this was achieved at a segmental level of $\mathrm{T}_{4}$. This observation suggests that the integrity of these pathways is essential for the prevention of autonomic dysreflexia in patients with low lesions, and that the interruption of these pathways in such patients is sufficient to create the state of autonomic dysreflexia without interruption of somatic pathways.

Whenever we observed a fall in blood pressure in patients with complete or incomplete cervical or high thoracic lesions, an explanation could be found in the individual case: the causes were either a prior subarachnoid injection of phenol or alcohol of the lower segments of the spinal cord, or operative haemorrhage. On the other hand, patients with lesions below the splanchnic outflow reacted similarly to normal patients in response to the magnitude of the intervention.

The magnitude and the site of the procedure determine whether or not the stimulus becomes liminal in the respective individual. A patient with a complete cervical lesion did not react during the incision of a palmar abscess which extended into the border area of normal and de-afferented skin. It is also known that pinprick stimulation at that site in such a patient produces, at best, a minimal rise of blood pressure. In contradistinction, vesical or perineal operations potentiated the response because these sites are notorious reflexogenic areas for autonomic dysreflexia. Renal and abdominal procedures had a similar effect.

\section{SUMMARY}

I. Ninety-seven patients with 257 surgical procedures were evaluated in regard to their blood pressure responses during various types of anaesthesia.

2. It was found that blood pressure changes during anaesthesia depended upon (a) the level of the lesion and $(b)$ on the magnitude and site of the procedure.

3. When the level was above the splanchnic outflow, the blood pressure rise, caused by autonomic dysreflexia, was frequently observed.

4. Renal operations, cervical laminectomies and spinothalamic tractotomies, and operations on the bladder and perineum on patients with high lesions, or with previous spinothalamic tractomies tend to raise the blood pressure.

5. In order to counteract these blood pressure rises, deepening the plane of anaesthesia was found preferable to the abrupt effect of ganglioplegic agents (hexamethonium chloride) because of better control. 


\section{RÉSUMÉ}

I. Les pressions sanguines au cours des différents types d'anesthésie chez 97 malades avec 257 interventions chirurgicales ont été étudiées. aient:

2. Il a été trouvé que les variations de pression sanguine pendant l'anesthésie dépend-

(a) de la lésion

(b) de l'importance et du siège de l'intervention.

3. Quand le niveau métamérique était au-dessus de l'émergence du splanchnique, une élévation de la tension artérielle en rapport avec l'hyper-réflectivité autonome a été fréquemment observée.

4. Quant aux opérations sur le rein, laminectomies cervicales, tractotomies spinothalamiques, opérations sur la vessie, le périnée des malades avec lésions hautes, ou tractotomisés, l'augmentation de la pression sanguine a été observée.

En vue d'éviter ces élévations de tension artérielle l'anesthésie en profondeur a été préférée à celle de l'action brutale d'agents ganglioplégiques (chloride d'hexamethonium) réalisant, en fait, un meilleur contrôle.

\section{ZUSAMMENFASSUNG}

I. 97 Patienten mit 257 chirurgischen Prozeduren wurden hinsichtlich ihrer Blutdruckreaktionen während verschiedener Anaesthesieverfahren analysiert.

2. Es wurde gefunden, dass Änderungen des Blutdrucks während der Anaesthesie hängen $\mathrm{ab}$ (I) von der Höhe der Läsion (2) von Grösse und Lokalisation der Operation.

3. Wenn die Höhe der Läsion oberhalb des Splanchnikusaustritts lag, der Blutdruck nahm zu und autonome Dysreflexie wurde häufig beobachtet.

4. Nierenoperationen, cervikale Laminektomie und Traktotomie des Tractus spinothalamicus sowie Operationen der Blase und des Perineum an Patienten mit hohen Läsionen und früheren spinothalamischen Traktotomieen zeigten eine Tendenz zur Blutdruckerhöhung.

5. Um diesen Blutdruckerhöhungen entgegen zu wirken, Vertiefung der Anaesthesia wurde dem plötzlichen Effect von Ganglion lähmenden Medikamenten wegen einer besseren Kontrolle vorgezogen.

\section{REFERENCES}

Barbella, J. D. \& Fink, A. E. (1952). Kessler Institute for Rehabilitation, I, 42.

Bors, E. \& FRENCH, J. D. (I952). Archives of Surery, 64, 803.

Ciliberti, B. J., Goldprein, J. \& Rovenstine, E. A. (I954). Anesthesiology, 15, 273.

Comarr, A. E. \& Woodard, M. (1957). Fournal of the American Association of Nurse Anesthetists, 25, 31 .

GeIger, C. (1964). Fournal of the American Association of Nurse Anesthetists, 32, 44.

GutTMANN, L. \& WhitTERIDGe, D. (1947). Brain, 70, 36I.

Kurfees, J. G. Whitehouse, S. \& Cerzosimo, F. (1949). Fournal of the American Medical Association, 141, 638.

LeE, C. (1965). Fournal of the American Association of Nurse Anesthetists, 33, 317.

Rocco, A. G. \& VAndam, L. D. (I959). Anesthesiology, 20, 348. 